УДК 811.161.1

\title{
ОСОБЕННОСТИ УПОТРЕБЛЕНИЯ И ТОЛКОВАНИЯ ИНОЯЗЫЧНЫХ НЕОЛОГИЗМОВ НА ПРИМЕРЕ ИНТЕРНЕТ-ВЕРСИЙ ПОПУЛЯРНЫХ ПЕЧАТНЫХ ИЗДАНИЙ
}

\author{
О. Ю. БАРАБАНЩИКОВА ОСОБЛИВОСТІ ВЖИВАННЯ І ТЛУМАЧЕННЯ ЗАПОЗИ- \\ ЧЕНИХ НЕОЛОГІЗМІВ НА ПРИКЛАДІ ІНТЕРНЕТ-ВЕРСІЇ ПОПУЛЯРНИХ ДРУКОВАНИХ \\ ВИДАНЬ
}

Проведене дослідження актуальне у зв'язку з зростаючою увагою до здатності мови "створювати повідомлення про себе саму», функиії тлумачення як характеристики металінгвістичної функиії, що актуалізуеться в комунікативних ситуачіях за допомогою типологічно визначених структур, які зводяться до біномінативної конструкиї щцо с щцо, а також з'ясуванню, чому тлумачення було потрібне $і$ як воно здійснювалося. Той факт, що прогалини в розумінні пов'язані головним чином з лексикою, - оскільки значення слова має бути пов'язане з певним денотатом (предметом, явищем), а незнайоме адресату слово передбачає роз'яснення за допомогою тлумачення у самому тексті, - спонукає до пошуку типологічно визначених синтаксичних моделей, здатних відображати ізоморфізм семантичних процесів на різних мовних рівнях. Вичленення з текстів ( саме в тексті значення слова проявлясться найактивніше $i$ одиниці мови тому здатні виражати і передавати думку при спілкуванні, щяо вони акумулювали в результаті функиіонування ії в текстах, мові, в процесі свого історичного розвитку, пов'язаного з діяльністю суспільства), проаналізованих електронних версій друкованих видань «Факти» $i$ «МК», метаздатних іншомовних одиниць дає наочне уявлення про матеріал дослідження, який в черговий раз доводить, що поповнення словника в значній мірі відбувається не внаслідок різних прочесів словотворення на базі існуючих в мові слів, а завдяки чужсомовним неологізмам, що стрімко входять в російську мову.

Ключові слова: лексична одиничя, металінгвістична функиія, семантична вага, статус слова, лексичні запозичення, вокабула, тлумачення.

\section{О. Ю. БАРАБАНЩИКОВА ОСОБЕННОСТИ УПОТРЕБЛЕНИЯ И ТОЛКОВАНИЯ ИНОЯЗЫЧНЫХ НЕОЛОГИЗМОВ НА ПРИМЕРЕ ИНТЕРНЕТ-ВЕРСИЙ ПОПУЛЯРНЫХ ПЕ- ЧАТНЫХ ИЗДАНИЙ}

Проведенное исследование актуально в связи со всевозрастающим вниманием к "способности языка создавать сообщение о себе самом», функиии толкования как характеристике металингвистической функции, которая актуализируется в коммуникативных ситуациях, посредством типологически определенных структур, принципиально сводимых к биноминативной конструкции что есть что, а также выяснению, почему потребовалось толкование и как оно осуществлялось. Тот факт, что пробель в понимании связаны главным образом с лексикой, - поскольку значение слова должно быть соотнесено с определенным денотатом (предметом, явлением), а незнакомое адресату слово предполагает разъяснение с помощью внутритекстового толкования, - побуждает к поиску типологически определенных синтаксических моделей, способных отражать изоморфизм семантических прочессов на различных языковых уровнях. Вычленение из текстов (ведь именно в тексте значение слова наиболее активно проявляется и единицы языка потому способны выражать и передавать при общении мысль, которую они аккумулировали в результате функционирования в текстах, в речи, в процессе своего исторического развития, связанного с деятельностью общества) проанализированных электронных версий печатных изданий “Факты” и “МК”, метаспособных иноязычных единии дает наглядное представление о материале исследования, которое в очередной раз доказывает, что пополнение словаря происходит в основном не за счет различных процессов словообразования на базе существующих в языке слов, а благодаря чужеязычным неологизмам, стремительно входящим в русский язык.

(C) О.Ю. Барабанщикова, 2019

https://doi.org/10.34142/2312-1572.2019.01.67.02 
Ключевые слова: лексическая единица, металингвистическая функиия, семантический вес, статус слова, лексические заимствования, вокабула, толкование.

\section{O.Y.BARABANSHCHYKOVA PECULIARITIES OF THE USAGE AND INTERPRETATION OF FOREIGN LANGUAGE NEOLOGISMS ON THE EXAMPLE OF INTERNET VERSIONS OF THE POPULAR PRINT EDITIONS}

Research that has been carried out has become relevant due to the growing interest and attention to the "ability of the language to create a message about itself", the interpretation function as a characteristic of the metalinguistic function, which is actualized in communicative situations, through typologically defined structures are as what is what, as well as clarifying why the interpretation was required and how it was carried out. The fact that gaps in understanding are mainly related to vocabulary - since the meaning of a word must be correlated with a certain denotation (object, phenomenon), and the unfamiliar word to the addressee implies an explanation using in-text interpretationleads to the search for typologically certain syntactic models capable reflect the isomorphism of semantic processes at different language levels. Extract from the texts (because it is in the text that the meaning of the word is most actively manifested and the units of language are therefore able to express and convey the thought in communication, which they accumulated as a result of functioning in the texts, in speech, in the process of their historical development associated with the activities of society) of the analyzed electronic version of printed periodic publications of "the Facts" and "MK" gives a visual representation of the research material, which once again proves that the replenishment of the lexical vocabulary in general does not occur due to various word-formation processes based on the words existing in the language, but thanks to neologisms, rapidly entering into the Russian language.

Key words: lexical unit, metalinguistic function, semantic weight, word status, lexical borrowing, vocable, understanding, interpretation.

Один из теоретических вопросов, ориентация в котором ведет к обеспечению полноценного речевого общения, базируется на тезисе об элементе н о в и з н ы, который содержится (или может содержаться) в лексической единице. Однозначный вывод - возникшее в социуме понятие определяет необходимость в слове, называющем это понятие - подкрепляется высказыванием Л. А. Булаховского: «живые потребности вызывают к жизни живые слова, лишенные каких-либо других претензий, кроме той, что они действительно понадобились» $[1, \mathrm{c.86}]$ и В.В.Виноградова: «Семантический вес и сфера применения иностранных слов обусловлены социальной оценкой категории явлений, всем устройством общественной жизни» $[4$, с.436].

Признанная исследователями необходимость учитывать время появления тех или иных реалий, а, следовательно, и их наименований (в частности, при периодизации лексики), наталкивает на труднопреодолимые препятствия в установлении хронологии появления и «приживления» новых терминов. Надежным показателем новизны слова именно для определенного исторического периода могут служить толкования, введенные в текст СМИ, в частности, газетных материалов, ведь они имеют неопровержимые даты выхода в свет. Посмотрим с этой точки зрения на недавние публикации в газете «Факты и комментарии» (русскоязычная всеукраинская ежедневная газета, издается с августа 1997 года) и «Московский комсомолец» (российская ежедневная общественно-политическая газета), оба издания выбраны за их частотность выхода в свет и непритязательную традиционность. Отмечая тот факт, что терминология как массив узкопрофессиональной лексики находит путь к широкому читателю именно благодаря средствам массовой информации (газетная лексика требует особых усилий при ее семантизации: осмысление, выявление содержания, значения), так как понимание этой лексики рядовым читателем затруднено или в связи с ее отсутствием в быстро стареющих словарях или через переосмысление семантического наполнения той или иной лексической единицы (фанера - строительный материал и фонограмма; винчестер - вид оружия и жесткий диск компьютера; развод - официальное завершение супружеских отношений и обман, мошенничество)

Пути просвещения читателя могут быть разными, наиболее простой (по крайней мере, наиболее распространенный) из них - введение понравившегося автору слова в заголовок, ведь заголовок статьи - это первое, на что читатель обращает внимание, обозначает тему, а часто и суть послания автора, однако помимо содержания, немаловажную роль играет и формулировка названия публикации с эффектным заголовком, во многом базирующимся на психологических аспектах личности, и здесь очень помогает особое слово, повышающее вовлеченность аудито- 
рии, такое слово также может выделяться размером и жирностью шрифта вроде вокабулы в словарях. Ни с этой ли целью за последний год в вышеуказанных изданиях появились заголов-

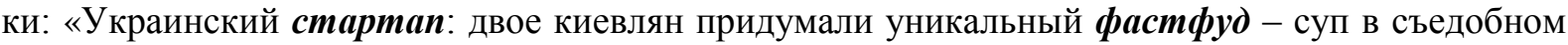
стаканчике» (Факты, 3 мая 2018 г.); «Самая колоритная глушь для дауншифтинга» (МК, 6 июня 2018 г.); «Работницы протестуют против харрасмента в Америке, Европе и Азии» (МК, 1 ноября 2018 г.); «22 февраля заканчивается льготная растоможка евроблях: как будет работать таможня» (Факты, 20 февраля 2019 г.).

На первый взгляд, по крайней мере, пять слов, взятых из приведенных заголовков, имеют право на статус неологизма, а, следовательно, вполне могут войти в лексикографические издания, потому что они еще не зафиксированы в Большом словаре иностранных слов - а это первый признак неологизма. К тому же, опираясь на компетентное мнение Н. 3. Котеловой, под новыми словами мы понимаем как собственно новые, впервые образованные или заимствованные из других языков слова (отсутствуют в словарях!), так и известные ранее слова, которые или принимались ограничено, за пределами литературного языка, или ушли из активного употребления, а ныне вновь стали широко применяемыми [6, с.7].

Действительно, слова делимитация (определение на географической карте) и дефолт, которые активизировались, в частности, при уточнении Украино-белорусской границы, границы Украина - Россия в Азовском море и угрожающего упадка финансовых дел государства («банкротство - всегда банкротство, даже названное иностранным словом дефолт») стоят едва ли не первыми (по крайней мере, в алфавитном порядке) в списке претендентов на то, чтобы, по выражению Л. А. Булаховского, «пойти вслед за своими собратьями, прокладывая дорогу к лексической элите » $[2,43]$.

Степень адаптации слова как свидетельство наличия или отсутствия в заимствующем языке равнозначных понятий является предметом специального исследования, однако трудно реально оценить возможность определения уровня освоения слова с помощью внешнего вида вокабул, воспроизводимых в иноязычных текстах. Способы передачи иноязычных вокабул в зависимости от уровня их освоения могут быть представлены следующим образом:

1. Перевод с помощью равнозначного или калькированного слова как единицы данного языка: Россия сама себя загнала в очень сложную ситуацию, - объяснил эксперт. - Есть такое положение в шахматах, которое называется «цугцванг» - принуждение кходу. Это когда любой твой ход приведет к неминуемому поражению. Не пропустить нас через пролив нельзя. Попал 8 настоящий иуцванг: Путину указали на серьезную ошибку с Украиной (Факты, 1 марта 2019).

2. Передача звучания слова с помощью транскрипции (транслитерации).

При транслитерации слово исходного языка передается средствами переводящего языка - графическая форма (буквенный состав) слова, а при транскрипции - его звуковая форма. Эти способы применяются при передаче иноязычных имен собственных, географических наименований и названий разного рода компаний, фирм, пароходов, газет, журналов и пр. Транслитерация также широко применяется при передаче реалий; она особенно распространена в общественно-политической литературе и публицистике как переводной, так и оригинальной, описывающей жизнь и события (например, в газетных корреспонденциях). Так, на страницах нашей прессы в последнее время стали встречаться следующие транскрипции английских слов и словосочетаний, не имеющих эквивалентов в русской лексике: tribalism - трайбализм, brainwash брейн-вош, publicschool - паблик скул, drugstore - драгстор, know-how - ноy-хаy, impeachment - импичмент и другие.

Мальиш родился 28 января. Вполне здоровенький, крепкий малыш: вес почти 3 кг, рост 48 см. Через 3 дня она избавилась от него. Слава богу, не выбросила на помойку, а принесла и положила его в спеииальный беби-бокс, оборудованный при больнице. Вчера после того, как губернатору продемонстрировали единственный на весь регион беби-бокс, снова вспыхнула дискуссия, нужны ли нам такие «спеиприемники» для новорожденных. (МК, 9 февраля 2019 г.)

Ради хайпа и популярности: 16-летняя обеспеченная школьница грабила ровесниц (МК, 13 февраля 2019 г.)

Одна голова хорошо, две - хайп: модный показ спровоцировал новый челлендж (МК, 27 февраля 2018 г.)

3. Введения в текст инкрустаций-украшений (иноязычных включений без пеервода) как сохранение подлинного облика слова, присущего языку-источнику заимствования. Приложение уже доступно в applestore и google play, - говорится в сообщении банка. (Факты, 12 января 2019 г.). Где осуществить обмен Bitcoin на Zcash по выгодному курсу (МК, 17 января 2019 г.). 
Встречаются и такие ситуации, когда достаточно сложно определить статус слова. Например, слово Апокалипсис, которое, собственно, и не исчезало из словарей, представлено в единственном значении: религиозно-мистическое произведение христианской литературы (6869 гг. н.э.), полное пророчеств о конце света [3, с.62], а также со страниц печатных изданий: Как ранее сообщали «Факты», библейский эксперт из США Пол Макгуайр утверждает, что нашел в Святом писании пророчество о конце света, который может произойти уже очень скоро, его причиной станет Третья мировая война, которая должна начаться в течение 30 ближайших лет. Вместо Нибиру летит «монстр из космоса»: ученые шокировали датой Anокалипсиса (Факты, 20 февраля 2019).

Попутно приведем заголовки статей, в которых слово апокалипсис написано с маленькой буквы: «Жуткое наводнение практически смыло город, кадры апокалипсиса», «Землетрясение в Италии стало апокалипсисом для старинного города Аматриче», «Ураган "Ирма" затопил Майами: страшные мгновения американского апокалипсиса».

Чтобы узаконить вторичное употребление слова Апокалипсис (но с маленькой буквы) в значении «всемирная катастрофа», делая упор не на перевод слова («Откровение»), а на содержание (пророчество о конце света), следует дополнить соответствующую словарную статью вторым пунктом, фиксируя таким образом н о в о е значение слова, пусть и основанное на ошибке, но уже достаточно распространеное (такие примеры лексикографической практике знакомы).

Попытки найти в публикациях «Фактов» или «МК» новообразования вроде «советизмов» прописка, авоська не увенчались успехом, так что вместо празднования развития национального языка, темп которого, по утверждению С. И. Ожегова [5, с.55], зависит от темпов развития общества, отмечаем обогащение лексических слоев заимствованиями, вступая тем самым в спор с Н. М. Шанским, который в свое время настаивал на приоритете именно национальноязыковых новообразований. Даже фразеологизмы, которые попали на страницы исследуемых СМИ - «Два года президентства Дональда Трампа: Хромая утка или Черный лебедь?» - перевод с английского, хромая утка (англ. lame duck) - в американской политической системе неформальное прозвище президента, который вскоре покинет свой пост, проиграв очередные выборы или не имея права выдвигать на них свою кандидатуру в соответствии с 22-й поправкой к Конституции США, а чёрный лебедь - теория, рассматривающая труднопрогнозируемые и редкие события, которые имеют значительные последствия, автор теории - Нассим Николас Талеб, который в своей книге «Чёрный лебедь. Под знаком непредсказуемости» (2007 г.) ввёл термин «события типа чёрный лебедь» (англ. TBS, The Black Swan).

\section{ЛИТЕРАТУРА:}

1. Булаховский Л. А. Курс русского литературного языка: в 2-х тт. М.: Радянська школа, т.1, $1952446 \mathrm{c}$.

2. Булаховский Л. А. Курс русского литературного языка: в 2-х тт. М.: Радянська школа, т.2, 1953. $434 \mathrm{c}$.

3. Большой современный толковый словарь русского языка, 2012. URL: https://slovar.cc/rus/tolk/917.html (дата доступа 10 марта 2019)

4. Виноградов В. В. Очерки по истории русского литературного языка XYII-XIX вв. М.: Высшая школа, 1982.529 с.

5. Ожегов С. И. Лексикология. Лексикография. Культура речи / Сергей Иванович Ожегов. - М.: Высшая школа, 1974. -352 с.

6. Словарь-справочник по материалам прессы и литературы 60-х годов / [под ред. Н. 3. Котеловой]. М.: Русский язык, 1971. 544 с.

7. Шанский Н.М. Основы словообразовательного анализа / Николай Максимович Шанский. - М.: Учпедгиз, 1953. -56 с.

Источники иллюстративного материала:

1. Факты .URL: https://fakty.ua (дата доступа18 марта 2019)

2. Московский комсомолец. URL: https://www.mk.ru (дата доступа 18 марта 2019)

(Статья поступила в редакциию 2 апреля 2019 г.) 